\title{
The Death of a Disease
}





\title{
The Death of a Disease
}

\section{A History of the Eradication of Poliomyelitis}

\author{
Bernard Seytre \\ Mary Shaffer
}

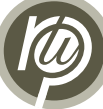

Rutgers University Press

New Brunswick, New Jersey, and London 
Originally published as Histoire de l'éradication de la poliomyélite, (C) Presses Universitaires de France, 2004.

\section{Library of Congress Cataloging-in-Publication Data}

Seytre, Bernard.

[Histoire de l'éradication de la poliomyélite. English]

The death of a disease : a history of the eradication of poliomyelitis / Bernard Seytre and Mary Shaffer ; translated by Mary Shaffer.

p. ; cm.

Includes bibliographical references and index.

ISBN-13: 978-0-8135-3676-7 (hardcover : alk. paper)

ISBN-13: 978-0-8135-3677-4 (pbk. : alk. paper)

1. Poliomyelitis-History. 2. Poliomyelitis vaccine-History.

[DNLM: 1. Poliomyelitis-prevention \& control. 2. History, 20th

Century. 3. Vaccination—history.] I. Shaffer, Mary. II. Title.

RC180.9.S4913 2005

616. 8'25-dc22

2005002654

A British Cataloging-in-Publication record for this book is available from the British Library.

Copyright (c) 2005 by Rutgers University Press

All rights reserved

No part of this book may be reproduced or utilized in any form or by any means, electronic or mechanical, or by any information storage and retrieval system, without written permission from the publisher. Please contact Rutgers University Press, 100 Joyce Kilmer Avenue, Piscataway, NJ 08854-8099. The only exception to this prohibition is "fair use" as defined by U.S. copyright law.

Manufactured in the United States of America 